https://dx.doi.org/10.4314/iijikm.v10i1.8

Information Impact:

Journal of Information and Knowledge Management

Vol. 10 (1), June, 2019

ISSN: 2141-4297 (Print) ISSN: 2360-994X (Online)

\title{
Knowledge of the Importance of Exclusive Breastfeeding among Lactating Young Mothers in Enugu Urban, Nigeria
}

\author{
${ }^{1}$ Benjamin U. Ugwoke, ${ }^{2}$ George E. Asogwa, ${ }^{3}$ Nelson E. Ezukwuoke
}

${ }^{1}$ Law Library, University of Nigeria, Enugu campus

${ }^{2}$ Enugu State University of Science and Technology (ESUT), Enugu, Nigeria

${ }^{3}$ College of Medicine, Enugu State University of Science and Technology, Enugu, Nigeria

Corresponding author uwadum@gmail.com

\begin{abstract}
This study focused on knowledge of the benefits of exclusive breastfeeding among young lactating mothers in Enugu urban, Nigeria. Four hospitals the young mothers used for their antenatal/ postnatal care were used for the study. They were Poly General Hosiptal, Asata, Enugu, New Haven Health Centre, Enugu, Balm of Gilead Hosiptal Achara Lay-out, Enugu and the National Orthopaedic Hospital, Enugu. The population of the study was made up of all the lactating young mothers who visited the hospitals with their infants for service. However, for data collection purpose, 80 copies of the questionnaire (20 copies to each hospital) were randomly shared among the young mothers in not less than two visits to each of the hospitals by the researchers. Sixty copies (70\%) of the questionnaire were properly completed and returned. Data collected were analyzed using percentage, frequencies and mean scores. Mean scores of 2.5 and above represented positive responses to the question items.The study has shown that $53(88.3 \%)$ of the respondents had knowledge of exclusive breastfeeding, while 7(11.6\%) of them did not have it. Majority of the young mothers were within the ages of 26-35 years old and most of them 42(70\%) had tertiary education. Many of them 23(38.3\%) were civil servants, followed by traders 19(13.6\%). 55(91.3\%) of the young mothers got information on the importance of exclusive breastfeeding from their hospitals and during antenatal/post-natal care. $28(46.6 \%)$ others got the information from their friends. The importance of exclusive breastfeeding had the following mean scores: Best food for infants 3.7; Baby looks healthy 3.3; Baby receives immunity against disease 3.0; strong bond between mother and child 3.0; it saves money 2.9; delays re-occurrence of menstruation 2.5, and fights against breast cancer 2.5. Uploading exclusive breastfeeding had the following mean scores: mother should feed on balanced diet (3.6); drink water adequately (3.4); and should be available 24 hours (2.7). Problems included maternal poor feeding (3.4); nature of mother's work (3.4); state of health (3.2) and maternal education (2.6).
\end{abstract}

Keywords: knowledge, Importance, Exclusive breastfeeding, Lactation, Young mothers, 
Ugwoke, B.U, Asogwa, G.E, Ezukwuoke, N.E: Knowledge of the Importance of Exclusive Breastfeeding among Lactating Young Mothers in Enugu Urban, Nigeria

\section{Introduction}

Knowledge is the product of information provided and received systematically on a given subject. Information is defined by Olajide(2008) as facts and opinions provided and received in the course of human daily activities. Facts communicated and received on a subject are capable of modifying the knowledge state of an individual (Afolabi, 2003). Acquisition and utilization of knowledge, especially in the area of health helps in preserving and enriching lives. Thus, provision of knowledge or facts on exclusive breastfeeding to young lactating mothers is necessary as its application encourages continuity of the natural process of human development which starts in the womb. This knowledge can be delivered orally, in print and non- print resource. It can also be delivered through the use of information and communication technologies such as radio and television stations. Exclusive breastfeeding is the provision of only breast milk as food for an infant without any other liquid except syrups which may be medicines or vitamins. Food is important in the life of every human being because it provides energy and nutrients required for activities, growth, repair and prevention of diseases (Olofin, 2016). When an infant is poorly fed, it becomes weak, loses weight and becomes inactive and can be easily attacked by infectious diseases.

Exclusive breastfeeding for six months is being recommended because it provides all the nutrients needed by the growing infant. According to kuchenbecker et al (2015), in a Malawian cross- sectional study on exclusive breastfeeding, it was found that while $58.8 \%$ of the male infants (105) whose mothers were interviewed had exclusive breastfeeding; 49'5\% did not receive it. On the part of the female infants (91), 41.2\% had exclusive breastfeeding, while $50.5 \%$ did not receive it. The infants who did not receive exclusive breastfeeding did not grow as others. It is a natural means of providing energy, nutrients and antibodies for fast growth and disease prevention in infants. It can be practised by lactating young mothers for six months and the breast milk should be given as demanded (Nlend and Ekani, 2010). As a way of encouraging exclusive breastfeeding, and preventing high mortality rates among infants, there should be improved maternal nutrition (Editorial, 2010). Since infants get their nutrition from their mothers, improved maternal nutrition means improved nutrition for the infants; the result is good health for the mothers and their infants because they feed on high 
Ugwoke, B.U, Asogwa, G.E, Ezukwuoke, N.E: Knowledge of the Importance of Exclusive Breastfeeding among Lactating Young

Mothers in Enugu Urban, Nigeria

quality foods. Breastfeeding is healthy for both the mother and the infant [Ejezie, 2018]. The major point in advocating exclusive breastfeeding is to avoid diarrhea and other related diseases capable of affecting the lives of the infants easily. One

\section{Statement of the Problem}

Experts in the health profession emphasize the need for lactating mothers to give their infants exclusive breastfeeding for at least the first six months. Some of them obey the

\section{Objectives of the Study}

The study is specifically intended to:

1. Ascertain the importance of exclusive breastfeeding as perceived by the lactating young mothers of 18 - 40 years old in Enugu urban.

\section{Literature Review}

Exclusive breastfeeding is recommended by experts in health profession for the first six months life of an infant. This is because it contains essential micronutrients, antibodies and antimicrobial agents [Ejezie, 2018]. The presence of these life supporting should be proud to carry an infant who looks healthy and who is active. Exclusive breastfeeding creates a rewarding opportunity for interaction between the mother and her child.

advice but others over look it. The problem is do these lactating young mothers who do not practise exclusive breastfeeding know its importance? What factors militate against them?

2. Know the major sources of their information on exclusive breastfeeding.

3. Find out factors militating against the practice of exclusive breastfeeding by young mothers.

elements help in fighting against diverse diseases. World Health Organization recommends that pregnant women in need of treatment of HIV should have access to anti- retroviral therapy to reduce mother- to child transmission and encourage breastfeeding intervention [ Horvath, T., Madi, B.C; Tuppa, 
T.M.(2009) cited in Nlend \& Ekani, 2010]. Proper treatment of HIV in pregnant mothers reduces its transmission to their infants through breastfeeding. UNICEF (2006), points out that exclusive breastfeeding stimulates babies' immune systems and protects them from diarrhea and acute respiratory infections. The organization indicates that Nigeria is among African countries that have made appreciable progress in exclusive breastfeeding since 1990. According to Sekyi and Anyobodeh(2016), exclusive breastfeeding provides an infant with superior nutritional contents capable of improving the infant's immunity and reduce expenses in future health care.

It is equally on records that the World Health Organization recommends exclusive breastfeeding for infants for Factors That Are Against Exclusive Breastfeeding

According to Ejezie(2018), insufficient provision of vitamin $\mathrm{D}$ through breastfeeding can lead to rickets among the infants. The mother's poor health during and after pregnancy can lead to inferior breast milk production the first six months because of the health implications. Healthy development of an infant is a natural process which starts in the womb of a pregnant woman. After birth, the mother is expected to ensure continued natural and right nutritional supply to the infant for at least six months

To Oyeniyi, (2015), exclusive breastfeeding reduces stress level because the practice involves relaxation. It is cheap, helps mothers lose weight and boosts the infant's intelligence. As a result of these important advantages to both the mothers and their infants, exclusive breastfeeding is cherished. It provides opportunity for skin- to- skin touch and eye contact between the mother and her infant. It restores uterus fast to its pre-pregnancy size and fights against breast cancer. [Yoddumnern - Attig, Attig and Kanungsukkasem, 1991]. The inferiority

of the breast milk can be seen in terms of its quantity and quality. An infant fed with poor breast milk appears unhappy and sickly. Low maternal micronutrients in take during lactation consequently lead to a reduction in the quality and 
quantity of same nutrients available for the infant in the breast milk [Ejezie, 2018]. Poor maternal nutrition is dangerous to the life of the infant whose food is the breast milk only. The absence of maternal care contributes largely to the poor growth of the affected baby who receives alternative nutritional substitute to breastfeeding.[Yoddumnern- Attig, Attig and kanungsukkasem, 1991]. Sekyi and Anyobodeh(2016) found that occupation, health condition, education and husband/ family support were the most militating factors against exclusive breastfeeding among lactating women in Sekondi-Takoradi Metropolis, Ghana. According to Ugboaja et al (2013), the major reasons for some women in the Southeastern Nigeria not involved in exclusive breastfeeding are their refusal to do it and their belief that it is stressful. Some of the lactating mothers in the area refuse exclusive breastfeeding because they want their breasts to remain firm and pointed. Others as a result of their worldly activities see sitting down to breastfeed their infants as extending the stress of the day. They also refuse exclusive breastfeeding if they do not eat well and the breast milk is not flowing as expected.

Kimani - Murage etal(2015) are of the view that poverty, livelihood and living arrangements, early and single motherhood, poor knowledge, HIV and unintended pregnancies are the major factors that militate against exclusive breast feeding in the poor urban setting of Nairobi, Kenya. Moreover, Setyaning et al (2018) found out in their study that mothers with low socio- economic status and others who had less knowledge of exclusive breast feeding did not involve themselves in the practice. The same authors discovered that mothers who were among the high income group employed the service of maids and did not involve themselves in exclusive breast feeding. In a study conducted by Igbal et al (2017), they discovered that mothers who did not practice exclusive breast feeding were not employed, belonged to lower socio-economic status, and lived in joint family system. According to Ajabode et al(2013), very low income and occupation such as peasant farming are other factors that do not support exclusive breastfeeding. 
Woldie et al (2014) found out through their study that some mothers in the urban areas were less likely to practice exclusive breast feeding as mothers in the rural communities. KL (2009) points out that infants who do not sleep with their mothers at night are not likely to receive exclusive breast feeding. The author equally states that many mothers who are from high income group do not practice exclusive breast feeding. One major reason some mothers do not

\section{Research Method}

The survey research method was used for this study. Questionnaire was used in collecting data from the lactating young mothers who were between the ages of 18 - 40 years. Twenty copies of the questionnaire were administered to the mothers who attended antenatal/postnatal care at each of the following hospitals:

a. Poly General Hosiptal, Asata, Enugu.

b. Balm of Gilead Hospital, Achara Lay-out, Enugu.

c. National Orthopaedic Hosiptal, Enugu.

d. New Heaven Health Centre involve themselves in exclusive breast feeding is their inability to lactate adequately (Kio, 2015). From the study conducted by Kimani - Murage et al(2015), it was found that many male infants could not be satisfied with breast milk feeding only. Hallmark News (2015) is of the view that other factors that are against exclusive breast feeding would include work outside the home, inadequate breast milk, ill-health and fear of sagging the breasts.
Provision of data by the young mothers was done voluntarily. The questionnaire was designed in Likert scale of Strong Agree (SA), Agree (A), Disagree (D) and Strong Disagree (SD). A total of 80 copies of the questionnaire were distributed among the respondents. However, $60(70 \%)$ copies of the questionnaire were properly completed and returned. Percentage was used in analyzing the first five questions. For the Likert scale used, the scores of each of the question items were allowed to attract a total of 10 marks shared in the following order: Strongly Agree $(\mathrm{SA})=4$, Agree $(\mathrm{A})=3$, Disagree $(\mathrm{D})=2$, Strong Disagree $(\mathrm{SA})=1$.

\begin{tabular}{|c|c|c|c|}
\hline SA & A & D & SD \\
\hline 4 & 3 & 2 & 1 \\
\hline
\end{tabular}


Mean $\frac{10}{4}=2.5$

Thus, 2.5 and above stand for acceptance.

Presentation of Results

Table 1: Demographic information of the Respondents.

\begin{tabular}{|l|l|l|l|}
\hline & Age Range & $\begin{array}{l}\text { Number of } \\
\text { responses }\end{array}$ & Percentage \\
\hline (a) & $18-25$ years & 12 & 20 \\
\hline (b) & $26-30$ years & 15 & 25 \\
\hline (c) & $31-35$ years & 22 & 36.6 \\
\hline (d) & $36-40$ years & 11 & 18.3 \\
\hline
\end{tabular}

Table 1 shows the following age ranges of the mothers;

(a) $18-25$ years $12(20 \%)$;

(b) 26-30 years $15(25 \%)$; (c) 31-35 years 17 (28\%); and

(d) $36-40$ years $11(18.3 \%)$.

Majority of the mothers were within the ages of 31-35 years old followed by those who were within 26-30years old.

\section{Table 2: $\quad$ Highest Level of Education}

\begin{tabular}{|l|l|l|l|}
\hline & Item & Number of Response & percentage \\
\hline (a) & No formal education & - & - \\
\hline (b) & Had Primary education only & - & - \\
\hline (c) & Had Secondary education & 16 & 26.6 \\
\hline (d) & Had tertiary education & 44 & 73.3 \\
\hline
\end{tabular}

Table 2 shows their educational levels in the following order:

(a) $44(73.3 \%)$ had tertiary education; (b) $16 \quad(26.6 \%)$ had secondary education;

(c) None of them had primary education only. 
Ugwoke, B.U, Asogwa, G.E, Ezukwuoke, N.E: Knowledge of the Importance of Exclusive Breastfeeding among Lactating Young Mothers in Enugu Urban, Nigeria

Majority of the mothers 44(73.3\%) had secondary education tertiary education, while others had

\section{Table3: Occupation}

\begin{tabular}{|l|l|l|l|}
\hline & Item & Number of Response & percentage \\
\hline (a) & Teacher & 6 & 10 \\
\hline (b) & Trader & 19 & 31.6 \\
\hline (c) & House wife & 11 & 18.3 \\
\hline (d) & Civil servant & 24 & 40 \\
\hline
\end{tabular}

In table 3, we are shown that $24(40 \%)$ of them were civil servants. 19(31.6\%) were traders, while $11(18.3 \%)$ were house wives, 6(10\%) were teachers. Majority of the mothers were civil servants and these were followed by traders.

Tables 4: Knowledge of Exclusive Breastfeeding

\begin{tabular}{|l|l|l|l|}
\hline Yes & Percentage & No & percentage \\
\hline 53 & $88.3 \%$ & 7 & $11.6 \%$ \\
\hline
\end{tabular}

Table 4 shows that $53(88.3 \%)$ of them had knowledge of exclusive breastfeeding,

While7 (11.6\%) did not have it

Table 5: Sources of information on Exclusive Breastfeeding

\begin{tabular}{|l|l|l|l|}
\hline & Item & $\begin{array}{l}\text { Number of } \\
\text { Response }\end{array}$ & percentage \\
\hline (a) & Libraries & 4 & 6.6 \\
\hline (b) & Radio & 13 & 21.6 \\
\hline (c) & Television & 14 & 23.3 \\
\hline (d) & Hospital: Antenatal/ Postnatal care & 55 & 91.6 \\
\hline (e) & Friends & 28 & 46.6 \\
\hline (f) & Internet & 14 & 23.3 \\
\hline
\end{tabular}


$55(91.6 \%)$ of them got the information from the hospitals (Antenatal/ post-natal care). 28 (46.6\%) got their information from their friends. 20(33.3\%) received the information from their family members. 14(23.3\%) got the information from the Internet, another
$14(23.3 \%)$ got the information from television. $13(21.6 \%)$ from radio and $4(6.6 \%)$ got their information from libraries. It can be seen that majority of them got their information from hospitals.

Table 6: The Importance of Exclusive Breastfeeding

\begin{tabular}{|c|c|c|c|c|c|c|c|}
\hline & Item & $\mathbf{S A}$ & $\mathbf{A}$ & $\mathbf{D}$ & SD & Mean & REMARK \\
\hline (a) & $\begin{array}{l}\text { Breast milk is the best food for children } \\
\text { below six Months }\end{array}$ & 176 & 42 & - & - & 3.6 & Accepted \\
\hline (b) & $\begin{array}{l}\text { When to breastfeed a baby is determined } \\
\text { by the mother only }\end{array}$ & 48 & 24 & 54 & 7 & 2.2 & Rejected \\
\hline (c) & Baby looks healthy & 148 & 57 & 2 & - & 3.4 & Accepted \\
\hline (d) & Baby is given immunity against diseases & 164 & 42 & 2 & - & 3.4 & Accepted \\
\hline (e) & It saves money & 132 & 33 & 8 & 3 & 2.9 & Accepted \\
\hline (f) & It stops bleeding after birth & 64 & 36 & 18 & 6 & 2.0 & Rejected \\
\hline$(\mathrm{g})$ & Strong bond between mother and the infant & 124 & 63 & 4 & 1 & 3.2 & Accepted \\
\hline (h) & It delays reoccurrence of Menstruation & 64 & 70 & 14 & 6 & 2.5 & Accepted \\
\hline (i) & It fights against breast cancer & 92 & 51 & 10 & 1 & 2.5 & Accepted \\
\hline
\end{tabular}

From table 6, we can see that the mean scores 3.6, 3.4, 3.2, 2.9 and 2.5 were rated positive, while the mean score 2.0 and 2.2were rated negative. 
Table 7: Factors against Exclusive Breastfeeding

\begin{tabular}{|l|l|l|l|l|l|l|l|}
\hline & Item & SA & A & D & SD & Mean & REMARK \\
\hline (a) & $\begin{array}{l}\text { Maternal poor feeding hinders her } \\
\text { exclusive breastfeeding. }\end{array}$ & 140 & 54 & 4 & 2 & 3.3 & Accepted \\
\hline (b) & $\begin{array}{l}\text { Maternal education can affect her } \\
\text { exclusive breastfeeding. }\end{array}$ & 72 & 72 & 10 & 7 & 2.6 & Accepted \\
\hline (c) & $\begin{array}{l}\text { Nature of a mother's work can affect her } \\
\text { practice of exclusive breastfeeding. }\end{array}$ & 112 & 75 & 6 & 1 & 3.2 & Accepted \\
\hline (d) & $\begin{array}{l}\text { State of health of the mother may not } \\
\text { Support exclusive breastfeeding. }\end{array}$ & 136 & 66 & - & 2 & 3.4 & Accepted \\
\hline
\end{tabular}

Table 7 shows the mean scores 3.4, 3.3, 3.2 and 2.6 which were all rated positive.

Table 8: $\quad$ How to Uphold Exclusive Breastfeeding.

\begin{tabular}{|l|l|l|l|l|l|l|l|}
\hline & Item & SA & A & D & SD & Mean & Remark \\
\hline (a) & $\begin{array}{l}\text { Mother should feed satisfactorily on } \\
\text { balanced diet every day. }\end{array}$ & 188 & 36 & - & - & 3.6 & Accepted \\
\hline (b) & $\begin{array}{l}\text { Mother should be available 24 hours } \\
\text { every day. }\end{array}$ & 108 & 51 & 20 & 2 & 3.0 & Accepted \\
\hline (c) & $\begin{array}{l}\text { Mother should drink water every day } \\
\text { adequately. }\end{array}$ & 136 & 75 & - & 1 & 3.5 & Accepted \\
\hline
\end{tabular}

All the means scores in this table 8: 3.6, 3.0 and 3.5 were all rated positive.

\section{Discussion of Findings}

In this study, it has been known that majority of the women $32(53 \%)$ were at the age range of 26-35 years. At that age, they should be able to maintain exclusive breastfeeding for their infants, having been adequately supported by their husbands/ families. Majority of them 44(73.3\%) received tertiary education and as such were in a position to appreciate the need for exclusive breastfeeding of their infants for at least the first six months.

Nigerian government grants each of the nursing mothers sixteen (16) weeks maternity leave to enable them take good care of their infants. On resumption of duty, 
each of them is allowed to dismiss from work at least two hours earlier than others. This gesture must be one of the reasons Nigeria has become one of the African countries that have made appreciable progress in exclusive breastfeeding since 1990 (UNICEF 2006). The implication is

\section{Conclusion}

The study has shown that exclusive breastfeeding has numerous advantages that should be harnessed by lactating young mothers for healthy development of their infants. This exclusive breastfeeding should be done for at least six months because of the advantages.

\section{References}

Adeyemo, M.O.A.(2013). Factors influencing the practice of exclusive breastfeeding in rural communities of Osun State, $\quad$ Nigeria. $\quad$ From https://www.iiste.org/journals/index/php/EJ $\mathrm{BM} /$ article/viewfile/6202/6308.accessed on 22-01-2019

Afolabi, A.k.(2003). Information needs, information sources and information seeking behavior of commercial vehicle drivers in Ondo State, Nigeria.Gateway Library Journal 6(2), December, 89-97.

Ajabode, B.L., Okunlade, J.O., Makinde,O.Y., Amoo, P.O. Benefits of exclusive breast feeding for 6 months. From that nurses in Nigerian hospitals spend time in teaching these young mothers the role of exclusive breastfeeding, and they have appreciably started to practice what they learn. There is hope for proper intellectual development and immunity of Nigerian children against diseases.

The various husbands/ families should support their lactating mothers to be able to practice exclusive breastfeeding effectively. The lactating mothers should not be allowed to participate in stressful works for the first six months they take adequate care of their infants.

https://www.boldsky.com/pregnancy-

parenting/post. accessed on 30-12-18.

Editorial (2010). Reducing neonatal death. Journal of Tropical Pediatrics 56(6), 371

Ejezie, F. E. (2018). Nature's tiny superheroes: An inaugural lecture of university of Nigeria, delivered on Thursday $29^{\text {th }}$ March.

Exclusive breast feeding for optimal growth, development and health of infants. From https://www.who.int/elena/titles/exculsivebreastfeedin/en/.accessed on 29-12-18. 
Ugwoke, B.U, Asogwa, G.E, Ezukwuoke, N.E: Knowledge of the Importance of Exclusive Breastfeeding among Lactating Young Mothers in Enugu Urban, Nigeria

Hallmarknews.com/ 7 reasons- Nigerianwomen-shun exclusive - breastfeeding. accessed on 22-01-2019.

Igbal, R.,Ali, M.,Amin, M. Saleem, M., Anwer, J. and Ali, S.(2017). Factors involved in failure of exclusive breast feeding practices among mothers. From jszmc.com/ files

pdf/JSZMCVolo8Noo1/1113.pdf accessed on $25 / 01 / 19$.

Kimani- Murage, E.W, Wekesah, F. Wanjohi, M., Kyobutungi, C. Eze, A,C, Musoke, R.N., Griffiths, P.(2015). Factors affecting actualization of the WHO breast feeding recommendations in urban poor setting in Kenya. Maternal and Child Nutrition 2(3), July, 314-332.

Kio, J.O(2015).Factors influencing breast feeding initiation and continuation among nursing mothers in Nigeria : Evidence from Lagos State. Journal of Nursing and Health Science 4(2), March to April, 1-7.

KL, T.(2009). Factors associated with nonexclusive breast feeding among 4 weeks post partum mothers in klang district, Peninsular, Malaysia. $\quad$ From www.nutriwed.org.my/publications/mjn001 5-/mjn15n/-art 2.pdf. accessed on 24-12019.http:// Www.who.int/elena/title/ exclusive breast feeding/en/. Exclusive breast feeding for optimal growth, development and health of infants accessed on 29-12-12018.

Kuchenbecker, J., Jordan I., Reinbott, A., Herrmann, J., Jeremias,T., Kennedy, G., Muehlhoff, E., Mtimuni, B. and Krawinkel, M.B.(2005). Exclusive breastfeeding and its effect on growth of Malawian infants: Results from a cross- sectional study. Paediatric Int Child Health 35(1): 14-23.

Nlend, A.E.N and Ekani, B.B (2010). Preliminary assessment of breast feeding practices in HIV infected mothers (prior to weaning) under the Djoungolo programme on the prevention of mother - to child transmission of HIV. Journal to Tropical Pediatrics 56(6), 436-438

Olajide, O.(2008) .Information needs of selected rural communities in Ekiti State, Nigeria. Nigerian Libraries 41, 55-67.

Olofin, O.A.(2016). Fundamental concepts of primary health care delivery system. Enugu. Immaculate Publications Ltd.

Oyeniyi, S.(2015). Benefits of exclusive breast feeding. From https:// the sheet.ng/ benefits- of -exclusive breast feeding. 
Ugwoke, B.U, Asogwa, G.E, Ezukwuoke, N.E: Knowledge of the Importance of Exclusive Breastfeeding among Lactating Young Mothers in Enugu Urban, Nigeria

accessed on 30-12-18. The benefits of breastfeeding from http://www.webmd.com/parenting/babynursi ng- $b$ accessed on 29-12-18.

Sekyi, E. and Anyobodeh(2016). Factors militating against exclusive breast feeding among lactating mothers in the SekondiTakoradi Metropolis, Ghana. European Journal of Food Science and Technology 4CI), January,18-28.

Setyaning, E.S, Rantetampang, A.L, Sandjaja, B and Mallongi(2018). Influential factors against exclusive breast feeding in working area of Wania District Health Center of Mimika Regency. International Journal of Science and Health Care Research 3(2), April - June, 206 - 211

Ugboaja, J.O., Nwosu, O.B., Igwegbe, A.O. and Obi- Nwosu,A.L.(2013). Barriers to postnatal care and exclusive breastfeeding among urban women in Southern Nigeria. Nigeria Medical Journal 54(1), January Feburary, 45 -50.

UNICEF(2006). Progress for children: A report card on nutrition, number 4, May. From https://www.unicef.org/progress for children/2006n4/index- breast feeding. html. accessed on 29-12-18.

Woldie, T.G., Kassa, A.W, and Edris, M.(2014). Assessment of exclusive breast feeding practice and associated factors in Mecha district, North West Ethopia . Science Journal of Public Health 2(4),330 336.

Yoddumnern- Attig, B, Attig, G and Kanugsukkasem. U.(1991). A people's perspective in nutrition education. World Health Forum 12, 406- 412. 